\title{
African Leaders: Their Education Abroad and FDI Flows
}

By

Amelie F. Constant

DIWDC, George Washington University, and IZA Bonn

constant@diwdc.org

and

Bienvenue N. Tien

DIWDC

tien@diwdc.org

December 2010

Corresponding Author:

Amelie Constant

Executive Director

DIWDC

1800 K Street, NW

Office Suite 716

Washington, DC 20006

Tel: 202.429.29.02

Fax: 202.429.29.07

constant@diwdc.org 


\title{
African Leaders: Their Education Abroad and FDI Flows
}

\author{
Amelie F. Constant \\ DIWDC, George Washington University, and IZA Bonn \\ and \\ Bienvenue N. Tien* \\ DIWDC
}

\begin{abstract}
:
Leaders are critical to a country's success. They can influence domestic policy via specific measures that they enforce, and they can also influence international public opinion towards their country. Foreign Direct Investments are also essential for a country's economic growth. Our hypothesis is that foreign-educated leaders attract more FDI to their country. Our rationale is that education obtained abroad encompasses a whole slew of factors that can make a difference in FDI flows when this foreign-educated individual becomes a leader. We test this hypothesis empirically with a unique dataset that we constructed from several sources, including the Library of Congress and the World Bank. Our analysis of 40 African countries employs the robust technique of conditional quantile regression. Our results reveal that foreign education is a significant determinant of FDI inflows, beyond other standard characteristics. While intuitive, this result does not necessarily indicate sheepskin effects or superior human capital obtained abroad. Rather, it indicates the powerful role of the social capital, networks, and connections that these leaders built while they were abroad that they in turn mobilize and utilize when they become leaders.
\end{abstract}

Keywords: FDI, Leaders’ Educational level, Return Migration, Africa

JEL Classification Codes: C31; C33; F21; I21

\footnotetext{
* The authors wish to acknowledge the comments of all participants at the World Bank's German Day on Development Conference, on November 3, 2010 in Washington, DC. We give special thanks to our discussant Abdu Muwonge (World Bank), Sonia Plaza (World Bank), Leopold R. Sarr (World Bank), Boniface Essama-Nssah (World Bank), Mwangi S. Kimenyi (Brookings Institute), and John Mutenyo (Brookings Institute).
} 


\section{Introduction}

Investing in human capital is the wisest and most lucrative investment an individual or a country can undertake. Human capital increases productivity both for the individual, who consequently commands higher earnings, and for the collective, which enjoys a higher output. Countries that want to emerge from underdevelopment or secure their worldwide preeminence have to invest consistently in human capital formation.

Human capital is very much interlinked with social capital, social behavior, and leadership effectiveness. Like human capital, social networks, connections, acquaintances, or contacts constitute resources that individuals use to pursue their interests and attain their goals. Social skills are an important subcomponent of individual human capital, and schooling plays a central role in developing such skills (Bowles and Gintis, 2001). People often forge longlasting friendships in college. Bourdieu and Wacquant (1992: 119) define social capital as "the sum of the resources, actual or virtual, that accrue to an individual or a group by virtue of possessing a durable network of more or less institutionalized relationships of mutual acquaintance and recognition."

Viewed as a web of social relationships, social capital can affect economic growth. Over the last decade, there have been serious efforts to place social capital in the development agenda. Knack and Keefer (1997) show evidence that social capital, operating through the channels of trust and civic norms, triggers investment and matters for measurable economic performance. In poorer countries, where financial sectors are less developed and contracts are not enforced, interpersonal trust as a form of social capital becomes crucial in facilitating economic activity and growth (Knack and Keefer, 1997).

Leaders matter for their country's growth (Jones and Olken, 2005), because they invest in generating contacts, they have the ability to choose the right direction for their country (Lazear, 
2010), they rely on interpersonal trust and built solidarity. An educated leader can set standards for success, place the right people in the right jobs to achieve the most effective performance, and inspire hard work and achievement. ${ }^{1}$

Free from colonial rulers in the 1960s, African countries faced an urgent necessity to build national administrations and to reconstruct their political and economic systems on their own. Many Africans educated overseas during colonialism returned to their newly independent countries to assume leadership or other prominent positions. However ambitious and eager to make a difference, African leaders were, the expected positive outcomes such as economic development, increased welfare and growth were hardly achieved. ${ }^{2}$

On the other hand, scientific evidence shows that foreign-educated repatriates can make tremendous contributions to their home country. For example, they can promote democracy in their home country when their education has been acquired in democratic countries (Spilimbergo, 2009). In fact, the educational and professional background of the head of government matters for the implementation of market-liberalizing reforms (Dreher et al., 2006). According to Besley et al. (2005), educated politicians generally can ensure a high quality of government because education significantly reduces the probability that an elected official uses his power opportunistically.

More importantly, educated leaders generate higher growth in their countries. Besley et al. (2009) show that a country's growth increases when it transitions from a non-educated leader to an educated leader. Furthermore, transitioning from an educated leader to a less educated leader,

\footnotetext{
${ }^{1}$ From a new longitudinal dataset based on interviews with twenty-six heads of universities in the U.S. and the UK, Goodall (2009), finds that, on average, the research quality of the university or the institution significantly improves after the institution appoints a president who is an accomplished scholar. A leader who is an established scholar commands respect and signals the priorities of the institution internally to its faculty as well as externally to potential new academic recruits, students, alumni, donors, and the media. She shows that organizational performance is improved when expert leaders are at the helm.

${ }^{2}$ The African economic take-off was hindered, inter alia, by political instability, policy choices, lack of basic growth enhancing institutions and capacity building. For a more extensive analysis on the way of governance and about some "policy syndromes" by African leaders see Collier et al. (2008) and Bates (2008). In section 2, we will present more details on the "first" African leaders and their characteristics. See also Table 2.
} 
the country's economic growth is negatively impacted and the impact is larger, the larger the education gap is between the two leaders. This finding that a change in the national leader is an important factor explaining sustained shifts in economic growth within a country is corroborated by other research (Jones and Olken, 2005).

Foreign Direct Investment (FDI) is also a major catalyst to long term growth and sustained economic development in a country (OECD 2002). It is an integral part of an open and effective international economic system and is crucial for developing countries in particular. In an "endogenous" growth framework, FDI directly impacts the accumulation of investment capital, speeds up technological advances, and boosts human capital accumulation (Barro, 1999). FDI is a significant means for technological transfers and contributes to economic growth more than domestic investment, albeit only when a sufficient absorptive capability of the advanced technologies is available in the receiving country (Borensztein et al., 1998).

FDI not only varies widely between the developed and developing world, but is also unevenly regionally distributed even within the African continent. In addition, the share of foreign investment varies widely among the different sectors (primary, secondary, and tertiary) (United Nations, 1999). While the economic and social development of Africa have been the subject of endless studies and many international resolutions, and while FDI flows have been analyzed and evaluated, little is known about the correlation between the educational attainment of the African leaders and inflows of foreign investments in their countries.

In this study, we combine all these elements (human capital, social capital, FDI and leadership) and conjecture that the foreign education of the leaders matters for FDI inflows in their home countries above and beyond standard determinants of FDI. Because people who invest in human capital also invest in social capital (Glaeser et al., 2002), social capital built abroad during the leaders' education period is the latent link that establishes the direction of FDI from 
Europe to Africa. We use unique data on the education of African leaders, FDI inflows and other important country characteristics that we compiled from a wide range of reliable sources. Since there is tremendous variability in the FDI distribution in Africa, it is important to study not only the mean but also the upper and lower ends of the distribution. A quantile regression is thus the appropriate estimation technique.

The rest of the paper is structured as follows. In section II, we describe the education of the early African leaders, their characteristics, and vision from independence to the present. We also discuss the economic orientation of the continent and review the relevant literature on the determinants of FDI in the region. In section III, we present our model and data and explicate our variables. In section IV we present and discuss summary statistics and the estimation results. We conclude in section V.

\section{From Colonialism to Independence and Beyond: Human Capital and Economic Matters II. 1. Education, Social Capital and Leadership in Africa}

Under colonialism, a number of young African scholars were going abroad, typically to the "mother" country, to acquire good education. After independence from the colonial rulers, many Africans continued to go to Europe for education that would enabled them to promote well-being in their home countries upon return.

The question that has been the subject of many discussions and debates is whether colonial education, that is, education that the "first" African leaders received, was in the best interest of their own people. By "first" leaders we mean those leaders who took over leadership immediately after independence. Interestingly, some of these leaders have been ruling their home countries, either as heads of states or as high officials, since independence from colonialism. 
B. W. Mkapa (2010), ex-president of Tanzania, classifies the African leaders who were in power before the end of the Cold War in six categories: the visionary idealists, the pragmatists, the incompetents, the military juntas, the tyrants and thieves, and a combination of two or more of the foregoing. He argues that "not only did colonial education not prepare those who received it for leadership [in the sense of helping their countries' economic take-off], but it was also not directed to the solution of economic and social problems of the newly independent countries" (p. 28).

Like human capital, individuals use social capital (consciously or even subconsciously) as a resource that helps them pursue their interests and attain their goals such as employment, migration, or community involvement. Coleman (1988) calls this the "appropriability" of social structure. Social capital mostly operates through the exchange of information which drastically reduces costs, and therefore it also raises productivity. Moreover, social capital is regarded by many as a new means to economic development. Some researchers even argue that because social capital affects relations among people, it should be an input or argument of the production and/or utility function (Schiff, 1992: p. 160). ${ }^{3}$

In general, going to a certain university can be viewed as belonging to a certain social group that shares the same values and the same habits of cooperation. In a group, social capital manifested through trust and group solidarity can be cemented by the sharing of hardship as well as by having common values and even by objecting some of the mainstream society's rules. Viewed as a web of social relationships, social capital provides opportunities and can affect economic growth. In the following, when we refer to the human capital that the leaders acquired abroad, we include the social capital component.

The education of the earlier leaders could have been influenced by the political system as well as by the actual education received at the higher institutions that leaders attended. All

3 Social capital is also defined as the "Glue Holding Society Together" on the World Bank's webpage http://www.worldbank.org/poverty/scapital/whatsc.htm. 
colonizing countries we refer to, whether they had a socialistic or a more conservative government, had democratic systems, followed democratic election processes, and complied with political and human rights laws. In practice, several African leaders failed to preserve and protect these ideals.

After the end of colonialism, many countries proceeded with the creation of sovereign democratic countries, often following their former colonizer's constitution and laws. One important point that they did not institute was a "terminal" leadership. Unlike European countries or the U.S., in Africa a leader can remain the president for many years, even sometimes until death. While an eternal benevolent leader can provide stability and allow his country to flourish, the eternal aspect of leadership can lead to monarchy, dictatorship, and abuse of power.

During the immediate post-colonial era, some Africans continued to go abroad to their former "mother" countries to receive education. Given that several "first" leaders are still in power, it is difficult to find African leaders who were educated during the post-colonial era or the post-cold war era. It is also difficult to speculate about the education and abilities of those educated in later years. During the post-cold war era, however, it is more common to find Africans going to other African countries for their education than outside the continent, because more African countries have built solid universities offering sound education and more European countries have tried to keep African students away. ${ }^{4}$

\section{2. FDI Flows and Economic Development in Africa}

FDI inflows are pivotal to the economic growth and development of a country. African countries need FDI the most. The first prerequisite for FDI to flow into a country is having an open economy participating in international trade. Looking back at the African continent, we find widespread skepticism about the virtues of free trade and foreign investment. Soon after

\footnotetext{
${ }^{4}$ Constant and Tien (2009) find that colonial vestiges constitute a strong determinant of the exodus of highly skilled and talented Africans to their former colonizers countries, even 40 years after de-colonization.
} 
independence and during the 1970s, several African countries imposed trade restrictions and capital controls as part of an import-substitution industrialization policy that aimed to protecting domestic industries and to conserving scarce foreign exchange (Dupasquier and Osakwe, 2005). Such an inward-looking economic development strategy not only discouraged international trade, but it also disenfranchised foreign direct investment, which ultimately had deleterious effects on economic growth and living conditions in the continent (Rodrik, 1998).

Realizing their disappointing economic performance and the pulverizing effects of globalization, many African countries opted for a regime shift. Thus, from the 1970s up to the mid-1990s, many African countries favored outward-looking development strategies. As a result, there has been relative improvement in economic performance in some countries since the mid1990s (Dupasquier and Osakwe, 2005; Fisher et al., 1998). In spite of the slight improvement, however, the overall growth pattern in Africa has remained anemic.

Table 1 shows the distribution of the world's FDI flows over the periods 1970 to 1990 and 1991 to 2009. It is striking that the developed countries received more than two thirds of the world's FDI inflows in both periods. Developing countries, however, received only about $22 \%$ in the period 1970 to 1990 , and about $31 \%$ in the second period. The entire African continent received a mere $3 \%$ of the world's FDI flows in the first period and 3\% in the second period. Evidently, Africa has never been a major recipient of FDI flows and naturally, the continent lags behind other regions of the world ${ }^{5}$ in spite its slight economic improvement.

$<$ Table 1 About Here $>$

Another feature worth noting in Africa is that FDI inflow distribution is uneven across regions. During the period 1970 to 1990 , the leading region was West Africa with $1 \%$ of the world's FDI. However, that region has lost its leadership in FDI inflows in the recent decades,

\footnotetext{
${ }^{5}$ For more details on the underlying reasons of Africa's economic retardation see Dupasquier and Osakwe (2005).
} 
falling down to $0.6 \%$. Northern Africa has been receiving $0.9 \%$ of FDI in both periods. FDI inflows is Eastern Africa have remained unchanged at $0.2 \%$ in both periods. Conversely, middle and southern African countries have been performing relatively well by attracting more FDI in the second period. According to the World Investment Report, UNCTAD (2002), most FDI to Africa are concentrated in the primary sector. Between 1996 and 2000, the primary sector accounted for $54 \%$ of FDI inflows in Africa. Next was the tertiary sector with $25 \%$, and lastly, the secondary sector with $21 \%$.

Studies on $\mathrm{FDI}^{6}$ to Africa are rather limited compared to other regions of the world. Basu and Srinivasan (2002) study some sub-Saharan countries that have succeeded in attracting considerable amounts of FDI. They document that key determinants of FDI inflows are sustained efforts to promote political and macroeconomic stability, implementation of essential structural reforms, and strong leadership as well as a firm commitment to economic reform. Examining Mali and Mozambique as well as some 27 other African countries, Morisset (2000) finds that by adopting specific actions in the 1990s, these two countries have been remarkably attractive to FDI. Beyond their macroeconomic and political stability, these actions included developing a few projects that have multiplier effects on investment projects and mounting an image-building effort with the participation of high political figures, including the president. The abundance of natural resources on the African continent and how they relate to FDI inflows has been the subject of some studies as well. Countries that are endowed with natural resources or countries with large markets attract significantly more FDI inflows (Asiedu, 2006; Morisset, 2000).

\footnotetext{
${ }^{6}$ Seven important elements attract foreign investors to a country (United Nations report, 1999):

1. The size of a country's market demand - measured by GDP per capita. 2. A fast pace of economic growth and the ensuing positive spiral created with more FDI and even higher growth. 3. Political stability evidenced through the absence of riots, coup d' étas and recurrent changes of governments. 4. Macroeconomic stability. 5. A well-developed infrastructure network and a well-trained labor force. 6 . A smooth administrative and regulatory environment along with transparent regulations. 7. Effective marketing efforts that promote the host country, given that other elements are fulfilled.
} 
On the monetary side, Rogoff and Reinhart (2003) suggest that the investment climate is adversely influenced by the odds of a civil war erupting or by ongoing wars. Wars seem to impose macroeconomic instabilities, such as frequent currency crashes and high inflation, that are deterrents to investment even in peacetime. Factors that are detrimental to FDI inflows in Africa are high dependency on commodities, increased competition for FDI among developing countries driven by globalization, weak governance (weak law enforcement), and poor and ineffective marketing strategies (Dupasquier and Osakwe, 2005).

\section{Model, Variables, and Data}

\section{1. Empirical Model and Hypotheses}

The previous sections have established the importance of having an educated leader and FDI inflows for the economic development and prosperity of a country. In this section, we seek to build a model that can address our question: can the foreign education of an African leader make a difference in the FDI flowing in his country above and beyond other standard explanatory variables? The dependent variable is FDI net inflows per capita in current U.S. dollars. The vector of independent variables includes the education of the country's leader plus a set of other determinants that affect FDI, that are in line with the established theory.

Previous analyses on FDI flows to Africa have employed either standard OLS or GMM techniques that concentrate on the conditional mean function of the dependent variable. However, when analyzing counties with large variability and a wide spread distribution (as it is the case of African countries) it is often important to look at the entire distribution and not just the mean. Multivariate quantile regression $(\mathrm{QR})$ is an especially suited estimation technique because it allows us to study the upper and lower tails of the distribution as well as to estimate the impact of regressors on the conditional distribution of the outcome. Our model is expressed as follows: 


$$
\mathrm{FDI}_{\mathrm{it}}=\beta(\mathrm{q}) \mathrm{Edu}_{\mathrm{i}}+\gamma(\mathrm{q})^{\prime} \mathrm{X}_{\mathrm{it}}+\varepsilon_{\mathrm{it}}(\mathrm{q})
$$

where the subscripts $i$ and $t$ stand for countries and time respectively. FDI $I_{i t}$ represents the flows of Foreign Direct Investments per capita in country $i$ at time $t . E d u_{i}$ is the education of a leader in country $i$ and $X_{i t}$ is a vector all other determinants. $\beta(q)$ and $\gamma(q)$ stand for the unknown parameters associated with the $\mathrm{q}^{\text {th }}$ quantile, with $\mathrm{q} \epsilon(0,1) ; \varepsilon_{i t}$ is the error term. We assume that the conditional $\mathrm{q}^{\text {th }}$ quantile of the error term is equal to zero, $\mathrm{Q}_{\varepsilon}(\mathrm{q} \mid \mathrm{Edu}, \mathrm{X})=0$, but the distribution of $\varepsilon_{i t}(q)$ is unspecified. Following Buchinsky (1998), in general, the $\mathrm{q}^{\text {th }}$ quantile regression $(0<\mathrm{q}<1)$ solves:

$$
\min _{\beta, \gamma} \frac{1}{n}\left\{\sum_{i, t: F D I \geq \beta^{\prime} E d u, \gamma^{\prime} X} q\left|F D I_{i t}-\beta^{\prime} E d u_{i}-\gamma^{\prime} X_{i t}+\sum_{i, t: F D I<\beta^{\prime} E d u, \gamma^{\prime} X}(1-q)\right| F D I_{i t}-\beta^{\prime} E d u_{i}-\gamma^{\prime} X_{i t} \mid\right\}
$$

As $\mathrm{q}$ increases from 0 to 1 , we can gauge the influence of the regressors on the entire conditional distribution of $F D I_{i t}$. However, in cases of heteroscedastic errors, the estimated standard errors are understated and robust standard errors should be calculated using bootstrapping techniques.

\section{2. Construction of Variables and Hypotheses}

We follow the World Bank's definition of FDI, which is defined as "the net inflows of investment to acquire a lasting management interest (10 percent or more of voting stock) in an enterprise operating in an economy other than that of the investor. It is the sum of equity capital, reinvestment of earnings, other long-term capital, and short-term capital as shown in the balance of payments." Using FDI per capita allows us to take the relative country size into account.

The variable $E d u_{i}$ stands for the leader's education. By education we mean the actual learning of the subject as well as the social capital built during the education period. The latter could be in the form of general knowledge that the leader acquired about the host country' organization and operation, or in the form of "business cards" that a leader accumulated over the years. Our hypothesis is that a leader who acquired his tertiary education outside Africa will 
attract significantly more FDI to his country than other leaders who were not educated or were educated within Africa. We construct three dummy variables: The variable Edu_Abroad takes the value 1 when a leader received his tertiary education outside of Africa; the variable Edu_Africa takes the value 1 when a leader received his tertiary education in Africa; and the variable No_Edu takes the value 1 when a leader had only secondary education from Africa or none of above. These dummy variables capture the precise impact that each educational level and place of the country leader has on FDI inflows. In the estimation the reference category is Edu_Africa.

$\boldsymbol{X}$ is a vector of standard independent variables that determine FDI according to theory and previous empirical evidence and $\varepsilon_{i t}$ is the disturbance term. Recent studies on FDI flows to Africa have established that first the literature on FDI to the continent is scant; second results from several investors surveys indicate that factor that attract FDI to Africa are different from factors that drive FDI in other regions, and third there is widespread perception that the region is structurally different from the rest of the world (c.f. Asiedu, 2006; Batra et al., 2003; Brunetti et al., 1997). An important determinant of FDI inflows in a country the number of years the leader is in power. The variable Tenure captures seniority and longevity in power. In principle, it signals stability in the country and some guarantee that the status quo will be maintained. The longer a leader stays in power, the more confidence investors will have in the country and the more FDI should flow into the country. Because of possible non-linear effects, we also include the square term of Tenure.

The next explanatory variable in $\boldsymbol{X}$ is the mode of assuming office, Power. This dummy variable captures the effect of whether a leader came to power through a democratic election (value $=1)$ or via a coup d'état $($ value $=0$ ). The idea is that military coups disrupt economic activity in the country and discourage foreign direct investment (Mkapa, 2010). However, even when a leader has been democratically elected he stays in power for a long time. Because the 
effect of Power on FDI may change with additional years in office we include the interaction term Power*Tenure.

Other important economic determinants of FDI flows that we include in $\boldsymbol{X}$ are: (i) the overall economic standing of the country or its market size. This is measured by the Gross National Income per capita $(G N I) .{ }^{7}$ We expect that a more economically prosperous country will attract more FDI (Busse and Hefeker, 2005; Chakrabarti, 2001); (ii) the share of a country's trade in GDP, denoted by the variable Openness. ${ }^{8}$ We conjecture that there is a positive relationship between trade and FDI; (iii) the Government's final consumption expenditure as share of GDP. This variable is denoted Gov-Exp. We expect that higher government expenditures indicate a positive trend, whereby investors know that there will be enough activity in the economy and they will receive a higher yield; (iv) the monetary side of the economy is an equally important consideration by investors. The variable $R E R$ denotes the official exchange rate, that is, local currency per U.S. dollar, period average.

The last set of important determinants of FDI inflows is related to ethnic diversity and civil liberties in the country. Recent studies have shown that countries with very high ethnic diversity tend to be more vulnerable to conflict eruptions that in turn impede economic development. Nigeria and Ethiopia are the most well-known countries in Africa that suffer from conflicts. On the other hand, countries with low ethnic diversity can flourish and advance economically, as manifested by the case for Botswana (c.f. Alesina et al., 2003; Easterly and Levine, 1997). We therefore expect an inverse relationship between ethnic diversity, denoted here as Ethnic and FDI. The variable Ethnic is a scale from zero to one, with one representing the highest ethnic diversity and zero denoting a homogeneous population.

\footnotetext{
${ }^{7}$ Since our dependent variable is FDI per capita it is optimal to use GNI per capita on the right hand side as well (Busse and Hefeke, 2005).

${ }^{8}$ The question of whether such a variable is appropriate for policy recommendation or not is beyond the scope of the present analysis. For more details see Asiedu (2006) and Rodriguez and Rodrik (2000).
} 
By civil liberties we mean the bill of rights, freedoms, and responsibilities of all individuals vis-à-vis their government. Civil liberties portray the social as well as the political climate in a country and include freedom of religion, freedom of speech, the right to due process, to a trial, to own property, and to privacy. Theoretically, countries where civil liberties are protected and safeguarded should attract more FDI. From the Freedom House World Country Rating 2009, we construct the index Civil that ranges from 1 to 7, with one representing the highest degree of freedom and the absolute guarantee of individual rights and with seven denoting an authoritarian government with no civil liberties.

\section{3. Data}

In this paper we employ a unique dataset, constructed by different data that we collected from several reliable sources and compiled. To create and construct the variable $E d u$, we searched several bibliographical sources at the Library of Congress to determine where each African leader received his tertiary education. We also double-checked our variables against other sources to make sure that we have a clean and valid variable. Similarly, for the variable Power, we gathered information from the Library of Congress and double checked our sources. Table 2 contains the 40 African countries for which we were able to find accurate information about the leaders' education. For each country, we provide the leader's name, place of education and the year(s) he is in power. Significantly, all the leaders in our sample are men.

\section{$<$ Table 2 About Here $>$}

The dependent variable FDI net inflows per capita comes from the World Investment Report (2010), UNCTAD online data base. All other economic variables were retrieved from the online African Development Indicators (2010) that are provided by the World Bank. For the variables capturing civil liberties and ethnic diversity in a country, we used two sources. The first 
comes from the Freedom House World Country Rating 2009. Information about the ethnic diversity in a country is taken from the index elaborated by Alesina et al. (2003). ${ }^{9}$

\section{Results}

\section{1. Sample Characteristics}

Table 3 provides the summary statistics of all the variables described above and employed in the model. On average, FDI net inflow per capita in the African countries in our sample is about $\$ 42$ and has a large standard deviation. Regarding the education of the leaders, four in ten of the leaders in our sample (40.3\%) received their tertiary education abroad (in Europe, America etc.), $27.5 \%$ received their tertiary education in Africa and $32.2 \%$ of them did not have any tertiary education.

$<$ Table 3 About Here $>$

The average time a leader spends in power in Africa is around thirteen years. Note that most African countries do not have a stipulation for an upper limit for years in power once elected. Table 3 also reveals that the majority of the African leaders in our sample (59.2\%) came to power through democratic elections. Nonetheless, $40.8 \%$ came to power military coups translating therefore a relative high dominance of military despotism in governance in the continent. Additionally, in our sample, GNI per capita in these countries is on average $\$ 2,337$. The overall openness of a country to trade as a percent of GDP is quite high. As trade is an important component in the African economies it occupies 70\% of GDP. Government expenditures constitute about $16 \%$ of the national product and the real exchange rate has an average of 216 .

The very high ethnic diversity on the continent is also shown by the raw data in Table 2 . On a scale from 0 to 1 , ethnic diversity scores 0.65 , on average. This indicates that the countries

\footnotetext{
${ }^{9}$ The correlation coefficients of the employed variables are reported in Table A-1 in the Appendix. Overall, the correlation coefficients are within normal parameters.
} 
and societies under study are not homogeneous and have noticeable ethnic and religious diversities. On average, the civil liberties index is at 5, revealing that the index tilts more towards fewer liberties. It is noteworthy to mention that, while the index is from 1 to 7 , no country in our sample scores one.

Based on raw data, Table 4 provides a closer look at net FDI inflows per capita to Africa by the leaders' place of acquired education. Clearly, leaders with education from abroad tend to attract more FDI (\$82.7) compared with their counterparts educated in Africa or those who did not receive any tertiary education. Interestingly, these figures change when we look at the lower quantile of the FDI distribution. The shares of net FDI per capita at the lowest $25^{\text {th }}$ quantile are about the same in all countries regardless of whether the leaders were educated abroad or not. However, at the $50^{\text {th }}$ quantile, it is clear that countries with leaders educated abroad attract more foreign investors - almost twice as much. At the upper $75^{\text {th }}$ quantile, leaders who acquired their tertiary education outside Africa are linked with high FDI flows in their country, much more than leaders who acquired their education in other African countries. Surprisingly, at the $50^{\text {th }}$ and $75^{\text {th }}$ quantile, leaders who did not receive any tertiary education attract more FDI than their homologues who were educated in Africa.

$<$ Table 4 About Here $>$

\section{2. Estimation Results}

Only a multivariate regression can elucidate the summary statistics results because it controlls for other characteristics and macro-economic junctures. In this section, we present the results of the conditional mean from an OLS estimation as well as for the $25^{\text {th }}, 50^{\text {th }}$ (median) and $75^{\text {th }}$ quantile of the distribution. In Table 5, we present OLS estimations with robust standard errors from a pooled sample of 40 countries and 40 leaders who were in office in 1990. Column (1) reveals that education of the country leader matters. While receiving education from abroad or from Africa are 
not significantly different in determining FDI inflows, having a non-educated leader (NO EDU) definitely leads to fewer foreign investments in the country, compared to having country leaders educated in Africa, the reference group. Hence, on average, educated leaders attract more foreign investment in their country, ceteris paribus. Education does not just reflect the actual degree obtained or sheepskin effects. It encompasses the exposure of the individual to a social network of peers that can prove to be very useful later in life.

$<$ Table 5 About Here $>$

Column (1) shows that the coefficients for the number of years in power are statistically significant and follow a smooth concave profile. As predicted, the more years a leader has in power, the more FDI flows in the country, albeit at a decreasing rate. Additionally, countries with leaders who are democratically elected also receive more FDI. Naturally, this is a positive signal that the leader will proceed with policies that will not be detrimental to foreign investors. However, because we also include an interaction term (Power*Tenure), we need to interpret our results more carefully. The coefficient of the interaction term shows that the effect of being democratically elected on FDI inflows is negative, the longer the leader stays in power.

With regards to the economic determinants, Gross National Income per Capita (GNI) is significant and positive. As expected, and in congruence with Busse and Hefeker (2005), the higher the GNI is the higher the foreign investments in a country are, holding all else constant. A high GNI portrays a higher lever of development that is alluring to investors. International trade is another significant variable. The more a country is open to international trade, the more foreign investors invest in that country. On the other hand, high government consumption is an impediment to FDI inflows in the country. Our results show that when government expenditures are high, there are fewer foreign investments. Our explanation is that big government consumption (budgétivore) may be seen as a signal that a country has high debt and therefore has 
a potential solvency problem that deters private investment. In addition, high government consumption through deficit spending can raise interest rates and crowd out private investment.

The last two determinants in the model are ethnic diversity and civil liberties. The existence of high ethnic and religious diversity in a country is a deterrent to FDI, but it is not statistically significant. This finding is consistent with that of Easterly and Levine (1997). The coefficient on civil liberties is highly significant and has an unexpected sign. That is, the fewer civil liberties there are in a country, the more FDI flows in. Our explanation is that in countries where civil liberties are not observed the likelihood to trample working rights and safety measures is much higher. For example, it may be easier to employ child labor and/or have workers work long hours in unsafe environments. All these lead to lower costs and a more profitable investment and could justify FDI inflows.

In Columns (2), (3), and (4) we present the results of the quantile regression. Robust standard errors are in parenthesis underneath the coefficients; they are produced by bootstrapping because of heteroscedastic errors ${ }^{10}$ (Gould, 1992 and 1997). Overall, the quintile results are similar to the OLS results, but slicing the distribution and looking at the different quintiles can enlighten our findings. A visible difference is that not many variables matter at the low $25^{\text {th }}$ quantile. This implies that when FDI inflows are very low, there is not much one can do to boost FDI. At the $50^{\text {th }}$ and $75^{\text {th }}$ quantile, however, several variables are significantly different than zero.

Compared to OLS findings, a noticeable difference concerns the education of the leader variables. At the medium $50^{\text {th }}$ quantile and in the upper $75^{\text {th }}$ quantile, the place where the leader obtained his education makes a significant difference for FDI inflows. Leaders educated abroad attract more FDI in their countries than their counterparts educated in Africa. This implies that at the upper end of the distribution, a leader who is educated abroad can attract a lot of FDI,

\footnotetext{
${ }^{10}$ At $\mathrm{P}=0.000(\operatorname{chi} 2(12)=99.27)$.
} 
controlling for everything else. However, at the low $25^{\text {th }}$ quantile, education abroad does not have any different effect than education in Africa. Put differently, leaders with no (tertiary) education are no different in attracting FDI than those educated in Africa at any level of the distribution.

To our surprise, neither more years in power nor being democratically elected are significant determinants of FDI by themselves. However, the coefficients on the interaction term Power*Tenure show that at the $50^{\text {th }}$ and $75^{\text {th }}$ quantiles a democratically elected leader attracts less FDI when he stays in power for a long time, there are no significant effects at the $25^{\text {th }}$ quantile.

Next, we find that Gross National Income per capita is a strong magnetic pole of FDI, but only at the $50^{\text {th }}$ and $75^{\text {th }}$ quantiles. This result suggests that high income countries have the phenomenon of convergence, ${ }^{11}$ but low-income countries do not. Openness to international trade is no longer a significant determinant to FDI inflows. While the coefficient of Openness is positive, it fails to achieve statistical significance. Similarly, government consumption is insignificant at any quantile of the distribution. Interestingly, real exchange rates, $R E R$, have a contractionary effect on FDI, but only in the upper $75^{\text {th }}$ quantile. This may be the result of different channels (i.e. relative wage channels, relative wealth channels, and imperfect capital market arguments) through which the exchange rates influence FDI (Goldberg 2009).

Contrary to the OLS results, higher ethnic and religious diversity is a significant deterrent to FDI inflows, but only at the low $25^{\text {th }}$ quantile of the distribution. The negative effect of higher ethnic diversity at the $25^{\text {th }}$ quantile is because the stakes of social instability are higher. Lastly, civil liberties are not significant at any quantile.

\footnotetext{
${ }^{11}$ This phenomenon is referred in the literature as a formation of "convergence clubs" (see Baumol, 1986; Quah, 1997, and Barreto and Hughes, 2004).
} 


\section{Summary and Concluding Remarks}

A good leader is vital in advancing his country economically and maintaining political stability. An educated leader can address challenges smoothly, without creating any ethnic cleavages or polarizing the country. An educated leader can also consider all sides, set realistic goals, set an example, and lead his country to higher growth. FDI is also important for a country's economic growth and developing countries need more of it, FDI. Nonetheless, FDI distribution remains skewed towards the developed world. Africa, a continent that urgently needs to advance economically, has received only about 3\% of the world's FDI for the past four decades.

In this paper, we study the importance of a leader's education in attracting and boosting FDI inflows, beyond other economic and ethnic characteristics. Specifically, we are interested in whether a leader's foreign education makes a difference in attracting FDI. We perceive education as encompassing social capital built during the leader's tenure abroad.

Our empirical estimation is based on a unique dataset that we compiled from several reliable sources. Our sample has 531 observations and 40 African countries. Raw statistics show that the majority of African leaders (40.3\%) in our sample received their tertiary education abroad; another $28 \%$ received their tertiary education in Africa. This is contrary to the popular misconception that African leaders are not well educated. Still, 32\% of the leaders in our sample received no tertiary education. On average, an African leader remains in power for 13 years and slightly more than half of the leaders are democratically elected while the others assume power by a military coup d'état.

We estimate both an OLS and a quantile regression that can better access the determining factors of foreign investment while looking at the entire distribution. Taken as a whole, the results from the econometric analysis indicate that having both a tertiary education and acquiring it from abroad matters for FDI inflows. OLS results show that when the leader is not educated it 
constitutes a deterrent to FDI inflows, thus confirming that an educated leader can increase his country's growth. The quintile results show more clearly that it is an education received from abroad rather than from Africa that makes a difference in attracting FDI. It is most interesting, however, that foreign-educated African leaders rather than domestically-educated leaders attract more FDI in their countries only at the $50^{\text {th }}$ and $75^{\text {th }}$ quintiles. Specifically, controlling for all other economic and geopolitical characteristics, the power of the leader's foreign education is compelling when the inflows of FDI are already high. These findings imply that the impact of education does not only come from sheepskin effects or superior human capital obtained abroad. Human capital in this case, embodies the powerful role of the social capital, networks, and connections that these leaders built and cultivated when they were students abroad. When they returned to their home country they kept this social capital alive, and they mobilized and utilized it to their benefit when they became leaders. At the bottom $25^{\text {th }}$ quantile, there is no significant difference between a foreign-educated leader and a domestically-educated leader in attracting FDI.

The duration of time that a leader is in power is important in attracting FDI, albeit at a decreasing rate. Similarly, a democratically elected leader attracts more FDI in his country. By interacting years in power and mode of assumption of office, we find that even if a leader is democratically elected, he affects FDI inflows negatively if he stays in office for long. This is quite intuitive since the longer a leader stays in power, the more likely it is that he will switch to an autocracy or dictatorship, therefore discouraging foreign investors and contracting FDI inflows.

A high Gross National Income per capita is another significant magnet to FDI. Moreover, this finding holds both at the average OLS and at the $50^{\text {th }}$ and $75^{\text {th }}$ quantiles. How open is a country to international trade is an important pull factor of FDI, but it holds only at the OLS results. High government expenditures significantly discourage foreign investors at the average. A 
high exchange rate is also a deterrent to FDI inflows, but this time only at the top $75^{\text {th }}$ quantile. That is, at the upper part of the FDI distribution a high exchange rate can put a halt on foreign investments in the country.

An interesting finding in this study is that at the bottom 25th quantile there are not many characteristics that matter for FDI inflows. The only exception is ethnic and religious diversity that can be significant barriers to FDI when we consider the lowest $25^{\text {th }}$ quantile. This implies that high ethnic diversity and its presumed festering civil war becomes relevant and impedes FDI inflows only when FDI inflows are already very low. At all other levels of the FDI distribution, foreign investors are not particularly concerned with ethnic diversity. Lastly, our OLS results show that all other things being equal, the less a country safeguards civil liberties the more FDI flows in the country. Civil liberties are not a significant consideration to foreign investors when we examine different quantiles for the FDI distribution. 


\section{References}

Alesina, A., A. Devleeschauwer, W. Easterly, S. Kurlat, and R. Wacziarg (2003). "Fractionalization." Journal of Economic Growth, 8 (2): 155-194.

Asiedu, E. (2006). "Foreign Direct Investment in Africa: The Role of Natural Resources, Market Size, Government Policy, Institutions and Political Instability." World Economy, 29 (1): 63-77.

Barreto, R. A., A. W. Hughes (2004). "Under Performers and Over Achievers: A Quantile Regression Analysis of Growth." Economic Record, 80 (248): 17-35.

Barro, R. J. (1999). "Notes on Growth Accounting." Journal of Economic Growth, 4 (2): 119-137.

Basu, A. and K. Srinivasan (2002). "Foreign Direct Investment in Africa - Some Case Studies." IMF Working Paper 02/61, Washington, DC.

Bates, R. (2008). "Political Reform." In B. Ndulu, S. O'Connell, R. Bates, P. Collier and C. Soludo (eds.), The Political Economy of Economic Growth in Africa, 1960-2000, Volume 1, Chapter 10. Cambridge, United Kingdom: Cambridge University Press.

Batra, G., D. Kaufmann and A. Stone (2003). Investment Climate Around the World: Voices of the Firms from the World Business Environment Survey. Washington, DC: World Bank.

Baumol, W. (1986). "Productivity, Convergence and Welfare: What the Long Run Data Show." American Economic Review, 76 (5): 1072-1085.

Besley, T., R. Pande and V. Rao (2005). "Political Selection and the Quality of Government: Evidence from South India." CEPR Discussion Paper No. 5201, London, UK.

Besley, T., J. G. Montalvo and M. Reynal-Querol (2009). "Do Educated Leaders Matter?" Discussion Paper downloaded from: www.econ.upf.edu/ reynal/delm_December_3.pdf

Borensztein, E., J. De Gregorio and J-W. Lee (1998). "How Does Foreign Direct Investment Affect Economic Growth?” Journal of International Economics, 45 (1): 115-135.

Bourdieu, P., and Wacquant, L. J. D. 1992. An Invitation to Reflexive Sociology. Chicago: University of Chicago Press.

Bowles, S., H. Gintis, and M. Osborne (2001). "The Determinants of Earnings: A Behavioral Approach," Journal of Economic Literature, vol. 39 (4), pp. 1137-76.

Brunetti, A., G. Kisunko and B. Wider (1997). "Institutional Obstacles to Doing Business: Region by-Region Results from a Worldwide Survey of the Private Sector." World Bank Policy Research Working Paper No. 1759, Washington, DC.

Buchinsky, M. (1998), "Recent Advances in Quantile Regression Models," Journal of Human Resources, 33 (1): 88-126.

Busse, M. and C. Hefeker (2005). "Political Risk, Institutions and Foreign Direct Investment." HWWA Discussion Paper 315, Hamburg, DE.

Chakrabarti, A. (2001). "The Determinants of Foreign Direct Investment: Sensitivity Analyses of Cross-Country Regressions.” Kyklos, 54 (1): 89-113.

Collier, P., R. Bates, A. Hoeffler and S. O’Connell (2008). "Endogenizing Syndromes." In B. Ndulu, S. O'Connell, R. Bates, P. Collier and C. Soludo (eds.), The Political Economy of Economic Growth in Africa, 1960-2000, Volume 1, Chapter 11. Cambridge, United Kingdom: Cambridge University Press.

Coleman, J. S. (1988). "Social Capital in the Creation of Human Capital," American Journal of Sociology, 94(Supplement): S95-S120. 
Constant, A. F. and B. N. Tien (2009). "Brainy Africans to Fortress Europe: For Money or Colonial Vestiges?” IZA Discussion Paper No. 4615, Bonn, DE.

Dreher, A., M. J. Lamla, S. M. Rupprecht and F. Somogyi (2006). "The Impact of Political Leaders' Profession and Education on Reforms." Swiss Institute for Business Cycle Working Papers No. 147, Zürich, Switzerland.

Dupasquier, C. and P. N. Osakwe (2005). "Foreign Direct Investment in Africa: Performance, Challenges and Responsibilities," Working in Progress No. 21, African Trade Policy Centre, Economic Commission for Africa.

Easterly, W. and R. Levine (1997). "Africa's Growth Tragedy: Policies and Ethnic Divisions," The Quarterly Journal of Economics, 112 (4): 1203-1250.

Freedom House (2009). Freedom in the World: Country Ratings 1972-2009. Washington, DC: Freedom House.

Glaeser, E. L., D. Laibson and B. Sacerdote (November 2002). “An Economic Approach to Social Capital," The Economic Journal, 112: F437-F458.

Goldberg, L. S. (2009). "Exchange Rates and Foreign Direct Investment." In K. A. Reinert, R. S. Rajan and A. J. Glass (eds), The Princeton Encyclopedia of the World Economy, Volume 1. pp.393-396. Princeton and Oxford: Princeton University Press.

Goodall, A. H. (2009). Socrates in the Boardroom: Why Research Universities Should be Led by Top Scholars. Princeton, NJ: Princeton University Press.

Jones, B. F. and Benjamin A. Olken (2005). "Do Leaders Matter? National Leadership and Growth since World War II," Quarterly Journal of Economics, 120 (3): 835-864.

Knack, Stephen and Philip Keefer (Nov., 1997) "Does Social Capital Have an Economic Payoff? A Cross-Country Investigation Source." The Quarterly Journal of Economics, Vol. 112, No. 4, pp. 1251-1288.

Lazear, E. P. (2010). "Leadership: A Personnel Economics Approach.” NBER Working Paper 15918, Cambridge, MA.

Makpa, W. B. (2010). "Leadership for Growth, Development, and Poverty Reduction: An African Viewpoint and Experience." In D. Brady and M. Spence (eds.), Leadership and Growth. Washington, DC: The World Bank.

Morisset, J. (2000). "Foreign Direct Investment in Africa: Policies also Matter." World Bank Policy Research Working Paper No. 2481, Washington, DC.

Munoz-Perez, B. and B. N. Tien (2007). "Elfenbeinkueste.” In W. Gieler (ed.), Die Aussenpolitik der Staaten Afrikas: Ein Handbuch: Aegypten bis Zentralafrikanische Republik. Paderborn: Ferdinand Schoeningh.

OECD (2002). Foreign Direct Investment for Development: Maximizing Benefits, Minimizing Costs. Paris: OECD.

Quah, D. T. (1997). "Empirics for Growth and Distribution: Stratification, Polarization and Convergence Clubs." Journal of Economic Growth, 2 (1): 27-59.

Rake, A. (2001). Guiding the New Millennium. Lanham, MD: Scarecrow Press, Inc..

Rodriguez, F. and D. Rodrik (2000). "Trade Policy and Economy: A Skeptic's Guide to the CrossNational Evidence.” In B. Bernanke and K. Rogoff (eds.), NBER Macroeconomics Annual 2000. Cambridge, MA: MIT Press.

Rodrik, D. (1998). "Trade Policy and Economic Performance in Sub-Saharan Africa." NBER Working Paper 6562. Cambridge, MA 
Rogoff, K. and C. Reinhart (2003). "FDI to Africa: The Role of Price Stability and Currency Instability." IMF Working Paper 03/10, Washington, DC.

Schiff, M. (1992). "Social Capital, Labor Mobility, and Welfare: The Impact of Uniting States," Rationality and Society, 4: 157-175.

Spilimbergo, A. (2007). "Democracy and Foreign Education." IMF Working Paper 07/51, Washington, DC.

Spilimbergo, A. (2009). "Democracy and Foreign Education," American Economic Review, 99 (1): 528-543.

UNCTAD (2010). World Investment Report. Online database under: http://www.unctad.org/ Templates/Page.asp?intItemID=1923\&lang=1 (accessed on August 31, 2010).

United Nations Conference on Trade and Development (1999). Foreign Direct Investment in Africa: Performance and Potential. New York and Geneva: United Nations.

World Bank (2010). African Development Indicators. Online database. http://data.worldbank.org/ data-catalog (accessed on August 26, 2010).

Ying, Y. T., A. Eng and E. Robinson (2010). "Perspective on Growth: A Political-Economy Framework - Lessons from the Singapore Experience.” In D. Brady and M. Spence (eds.), Leadership and Growth. Washington, DC: The World Bank. 
Table 1: Average FDI Inflows for the World and Selected Regions; 1970-1990 and 1991-2009

\begin{tabular}{|c|c|c|c|c|}
\hline \multirow[b]{2}{*}{ Regions } & \multicolumn{2}{|c|}{$1970-1990$} & \multicolumn{2}{|c|}{ 1991-2009 } \\
\hline & $\begin{array}{l}\text { Average } \\
\text { Inflows } \\
\text { (in Mill.) }\end{array}$ & $\begin{array}{l}\text { As a Share } \\
\text { of World } \\
\text { Inflows }\end{array}$ & $\begin{array}{l}\text { Average } \\
\text { Inflows } \\
\text { (in Mill.) }\end{array}$ & $\begin{array}{l}\text { As a Share } \\
\text { of World } \\
\text { Inflows }\end{array}$ \\
\hline World & $65,533.5$ & 100 & $810,274.3$ & 100 \\
\hline All Developing Economies & $14,291.1$ & 21.8 & $247,719.5$ & 30.6 \\
\hline All Developed Economies & $51,234.9$ & 78.2 & $536,695.6$ & 66.2 \\
\hline Africa & $1,719.2$ & 2.6 & $23,081.5$ & 2.8 \\
\hline Eastern Africa & 150.1 & 0.2 & $2,015.4$ & 0.2 \\
\hline Middle Africa & 227.1 & 0.3 & $5,846.2$ & 0.7 \\
\hline Northern Africa & 568.8 & 0.9 & $7,681.5$ & 0.9 \\
\hline Southern Africa & 115.8 & 0.2 & $2,936.2$ & 0.4 \\
\hline Western Africa & 657.5 & 1.0 & $4,602.4$ & 0.6 \\
\hline America & $4,898.8$ & 7.5 & $74,861.4$ & 9.2 \\
\hline Asia & $7,529.2$ & 11.5 & $149,154.9$ & 18.4 \\
\hline Oceania & 143.9 & 0.2 & 621.6 & 0.1 \\
\hline Developing Economies Excluding China & $13,354.3$ & 20.4 & $196,489.8$ & 24.2 \\
\hline Africa Excluding South Africa & $1,672.3$ & 2.6 & $20,667.3$ & 2.6 \\
\hline Northern Africa Excluding Sudan & 566.2 & 0.9 & $6,660.1$ & 0.8 \\
\hline Sub-Saharan Africa & $1,153.1$ & 1.8 & $16,421.5$ & 2.0 \\
\hline Sub-Saharan Africa Excluding South Africa & $1,106.2$ & 1.7 & $14,007.2$ & 1.7 \\
\hline
\end{tabular}

Source: World Investment Report (2010); Own estimations. 
Table 2: Selected African Countries and Characteristics of Leaders in 1990

\begin{tabular}{|c|c|c|c|c|c|}
\hline \multirow[b]{2}{*}{ Country } & \multicolumn{5}{|c|}{ Leaders' Characteristics } \\
\hline & Last Name & First Name & Dates in Power ${ }^{1}$ & $\begin{array}{c}\text { Country of } \\
\text { Tertiary } \\
\text { Education } \\
\end{array}$ & $\begin{array}{c}\text { Country of } \\
\text { Other } \\
\text { Education } \\
\end{array}$ \\
\hline Angola & Dos Santos & Jose Eduardo & Sep. 10, $1979-$ & $\begin{array}{c}\text { USSR } \\
\text { (Russia) }\end{array}$ & . \\
\hline Benin & Kerekou & Mathieu & $\begin{array}{l}\text { Oct. 26, } 1972- \\
\text { April 4, } 1991\end{array}$ & France & \\
\hline Cameroon & Biya & Paul & Nov. $6,1982-$ & France & . \\
\hline Chad & Habre & Hissene & $\begin{array}{l}\text { June } 7,1982- \\
\text { Dec. } 1,1990\end{array}$ & France & . \\
\hline $\begin{array}{l}\text { Congo, Dem. } \\
\text { Republic }\end{array}$ & Seko & $\begin{array}{l}\text { Mobutu Sese } \\
\text { (Joseph) }\end{array}$ & $\begin{array}{l}\text { Nov. } 25,1965- \\
\text { May } 16,1997\end{array}$ & . & Belgium \\
\hline $\begin{array}{l}\text { Congo, } \\
\text { Republic of }\end{array}$ & $\begin{array}{l}\text { Sassou- } \\
\text { Nguesso }\end{array}$ & Denis & $\begin{array}{l}\text { Feb. } 8,1979- \\
\text { Aug. 31, } 1992\end{array}$ & . & Algeria France \\
\hline Côte d'Ivoire & $\begin{array}{l}\text { Houphouet- } \\
\text { Boigny }\end{array}$ & Felix & $\begin{array}{l}\text { Aug. 7, } 1960- \\
\text { Dec. 7, } 1993\end{array}$ & Senegal & . \\
\hline Egypt & Mubarak & Hosni & Oct. $14,1981-$ & Egypt & . \\
\hline $\begin{array}{l}\text { Equatorial } \\
\text { Guinea }\end{array}$ & $\begin{array}{l}\text { Obiang } \\
\text { Nguema }\end{array}$ & Teodoro & Oct. $12,1982-$ & Spain & . \\
\hline Ethiopia & Haile Mariam & Mengistu & $\begin{array}{l}\text { Sep. 10, } 1987- \\
\text { May 21, } 1991\end{array}$ & Ethiopia & . \\
\hline Gabon & Bongo & Omar & $\begin{array}{l}\text { Nov. } 28,1967- \\
\text { June } 8,2009\end{array}$ & . & Chad \\
\hline Gambia, The & Jawara & Sir Dawda & $\begin{array}{l}\text { April 24, } 1970- \\
\text { July 22, } 1994\end{array}$ & The UK & . \\
\hline Ghana & Rawlings & Jerry & $\begin{array}{l}\text { Dec. 31, } 1981- \\
\text { Jan. 7, } 1993\end{array}$ & . & Ghana \\
\hline Guinea & Conte & Lansana & $\begin{array}{l}\text { April 3, } 1984- \\
\text { Dec. 22, } 2008\end{array}$ & . & . \\
\hline Kenya & Moi & Daniel Arap & $\begin{array}{l}\text { Aug. 22, } 1978- \\
\text { Dec. } 30,2002\end{array}$ & Kenya & . \\
\hline Lesotho & Lekhanya & Justin & $\begin{array}{l}\text { Jan. 24, } 1986- \\
\text { May 2, } 1991\end{array}$ & . & . \\
\hline Liberia & Doe & Samuel K. & $\begin{array}{l}\text { July } 25,1984- \\
\text { Sep. } 9,1990\end{array}$ & . & . \\
\hline Madagascar & Ratsiraka & Didier & $\begin{array}{l}\text { Jan. 4, 1976- } \\
\text { March 27, } 1993\end{array}$ & France & . \\
\hline Malawi & Banda & Hastings K. & $\begin{array}{l}\text { July 6, } 1966- \\
\text { May 21, } 1994\end{array}$ & The U.S. & The UK \\
\hline Mali & Traore & Moussa & $\begin{array}{l}\text { June } 19,1979- \\
\text { March 26, } 1991\end{array}$ & France & . \\
\hline Mauritania & Taya & $\begin{array}{l}\text { Maaouya } \\
\text { Ould }\end{array}$ & $\begin{array}{l}\text { Dec. 12, } 1984- \\
\text { April 18, } 1992\end{array}$ & Mauritania & . \\
\hline Mauritius & Jugnauth & Aneerood & $\begin{array}{l}\text { June 16, } 1982- \\
\text { Dec. 22, } 1995\end{array}$ & The UK & . \\
\hline
\end{tabular}


Table 2: Selected African Countries and Characteristics of Leaders in 1990

\begin{tabular}{|c|c|c|c|c|c|}
\hline \multirow[b]{2}{*}{ Country } & \multicolumn{5}{|c|}{ Leaders' Characteristics } \\
\hline & Last Name & First Name & Dates in Power ${ }^{1}$ & $\begin{array}{c}\text { Country of } \\
\text { Tertiary } \\
\text { Education }\end{array}$ & $\begin{array}{c}\text { Country of } \\
\text { Other } \\
\text { Education }\end{array}$ \\
\hline Morocco & Mohammed & $\begin{array}{l}\text { Mawlay al- } \\
\text { Hasan II ibn }\end{array}$ & $\begin{array}{l}\text { Feb. 26, } 1961- \\
\text { July 23, } 1999\end{array}$ & Morocco & France \\
\hline Mozambique & Chissano & Joaquim & $\begin{array}{l}\text { Nov. 6, } 1986- \\
\text { Feb. 2, } 2005\end{array}$ & France & Portugal \\
\hline Namibia & Nujoma & Sam & $\begin{array}{l}\text { March 21, } 1990- \\
\text { March 21, } 2005\end{array}$ & . & . \\
\hline Niger & Seibou & Ali & $\begin{array}{l}\text { Dec. } 18,1989- \\
\text { April 16, } 1993\end{array}$ & Niger & . \\
\hline Nigeria & Babangida & Ibrahim & $\begin{array}{l}\text { Aug. 27, } 1985- \\
\text { Jan. 4, } 1993\end{array}$ & The UK & . \\
\hline Rwanda & Habyarimana & Juvenal & $\begin{array}{l}\text { July 5, } 1973- \\
\text { April 6, } 1994\end{array}$ & Zaïre & Zaïre \\
\hline $\begin{array}{l}\text { São Tomé and } \\
\text { Príncipe }\end{array}$ & Costa & $\begin{array}{l}\text { Manuel Pinto } \\
\mathrm{Da}\end{array}$ & $\begin{array}{l}\text { July12, } 1975- \\
\text { March 4, } 1991\end{array}$ & . & . \\
\hline Senegal & Diouf & Abdul & $\begin{array}{l}\text { Jan. 1, } 1981- \\
\text { April 1, } 2000\end{array}$ & France & . \\
\hline Seychelles & Rene & France Albert & $\begin{array}{l}\text { June5, } 1977- \\
\text { April 14, } 2004\end{array}$ & The UK & The UK \\
\hline Sierra Leone & Momoh & Joseph Saidu & $\begin{array}{l}\text { Nov. 28, } 1985- \\
\text { April 29, } 1992\end{array}$ & . & $\begin{array}{l}\text { Ghana, } \\
\text { Nigeria and }\end{array}$ \\
\hline Somalia & Barre & $\begin{array}{l}\text { Mohammed } \\
\text { Siad }\end{array}$ & $\begin{array}{l}\text { July } 1,1976- \\
\text { Jan. } 27,1991\end{array}$ & Italy & . \\
\hline South Africa & de Klerk & F.W. & $\begin{array}{l}\text { Aug. 15, } 1989- \\
\text { May 10, } 1994\end{array}$ & South Africa & . \\
\hline Sudan & Al-Bashir & Omar & $\begin{array}{l}\text { June } 30,1989- \\
\text { Oct. } 16,1993\end{array}$ & . & Egypt \\
\hline Sudan & Al-Bashir & Omar & Oct. $16,1993-$ & . & Egypt \\
\hline Tanzania & Mwinyi & Ali Hassan & $\begin{array}{l}\text { Nov. 5, } 1985- \\
\text { Nov. 23, } 1995\end{array}$ & Tanzania & The UK \\
\hline Togo & Eyadema & Gnassingbe & $\begin{array}{l}\text { April 14, } 1967- \\
\text { Feb. 5, } 2005\end{array}$ & . & . \\
\hline Tunisia & Ali & $\begin{array}{l}\text { Zine El } \\
\text { Abidine Ben }\end{array}$ & Nov. 7, $1987-$ & France & The U.S. \\
\hline Uganda & Museveni & Yoweri & Jan. 26, $1986-$ & Tanzania & . \\
\hline Zimbabwe & Mugabe & Robert & Dec. $31,1987-$ & South Africa & The UK \\
\hline
\end{tabular}


Table 3: Descriptive Statistics and Codes

\begin{tabular}{lcccc}
\hline Variables & Mean & Std. Dev. & Min & Max \\
\hline FDI (in USD) & 41.56 & 154.74 & -447.00 & 1935.09 \\
EDU_ABROAD (\%) & 0.40 & 0.49 & $0(\mathrm{NO})$ & 1 (YES) \\
EDU_AFRICA (\%) & 0.28 & 0.45 & $0(\mathrm{NO})$ & 1 (YES) \\
NO_EDU (\%) & 0.32 & 0.47 & $0(\mathrm{NO})$ & 1 (YES) \\
TENURE in years & 13.11 & 8.87 & 1 & 41 \\
POWER (\%) & 0.59 & 0.49 & 0 (Coup) & 1 (Election) \\
GNI (in USD) & 2336.89 & 3106.18 & 180.00 & 16230.00 \\
OPENNESS (\% of GDP) & 70.33 & 37.01 & 6.32 & 275.23 \\
GOV-EXP (\% of GDP) & 15.61 & 7.19 & 2.29 & 54.52 \\
RER (in USD) & 216.22 & 491.53 & 0.00 & 9675.78 \\
ETHNIC_DIV(index 0-1) & 0.65 & 0.23 & 0.04 & 0.93 (high diversity) \\
CIVIL (index 1-7) & 5.21 & 1.28 & 2 & 7 (No civil liberties) \\
\hline
\end{tabular}

Table 4: Descriptive Statistics of FDI by Place of Leaders' Education

\begin{tabular}{lcccccccc}
\hline & & & & & \multicolumn{3}{c}{ Quantiles } \\
\cline { 7 - 9 } & Mean & Std. Dev. & Min & Max & $\mathbf{2 5}^{\text {th }}$ & $\mathbf{5 0}^{\text {th }}$ & $\mathbf{7 5}^{\text {th }}$ \\
\hline Leader Educated Abroad & 82.70 & 227.02 & -31.40 & 1935.08 & 0.75 & 5.70 & 29.79 \\
Leader Educated in Africa & 6.98 & 15.55 & -5.75 & 144.62 & 0.78 & 2.78 & 7.09 \\
Leader with No Education & 17.98 & 69.61 & -447.00 & 296.79 & 0.18 & 3.13 & 17.73 \\
All Together & $\mathbf{4 1 . 5 6}$ & $\mathbf{1 5 4 . 7 4}$ & $\mathbf{- 4 4 7 . 0 0}$ & $\mathbf{1 9 3 5 . 0 8}$ & $\mathbf{0 . 4 9}$ & $\mathbf{3 . 5 6}$ & $\mathbf{1 6 . 1 8}$ \\
\hline
\end{tabular}


Table 5: Estimated Results: FDI per Capita and Leaders' Education

\begin{tabular}{|c|c|c|c|c|}
\hline \multirow[b]{2}{*}{ Variables } & \multirow{2}{*}{$\begin{array}{l}\text { Robust OLS } \\
\text { Regression }\end{array}$} & \multicolumn{3}{|c|}{ Quantile Regression } \\
\hline & & $25^{\text {th }}$ Quantile & $50^{\text {th }}$ Quantile & $75^{\text {th }}$ Quantile \\
\hline \multirow{3}{*}{ Constant } & (1) & (2) & (3) & (4) \\
\hline & $-164.181 * * *$ & 1.456 & $-16.385^{* *}$ & $-25.662 *$ \\
\hline & (39.243) & $(7.596)$ & $(6.737)$ & $(14.331)$ \\
\hline \multirow{2}{*}{ EDU_ABROAD } & 1.280 & 0.642 & $5.447 * * *$ & $16.252 * * *$ \\
\hline & (7.909) & $(1.253)$ & $(1.889)$ & $(4.602)$ \\
\hline \multirow[t]{2}{*}{ NO_EDU } & $-78.934 * * *$ & -0.607 & -4.305 & -6.843 \\
\hline & $(16.610)$ & $(1.704)$ & $(2.914)$ & $(5.831)$ \\
\hline \multirow{2}{*}{ TENURE } & $5.225 * * *$ & -0.037 & 0.281 & 0.465 \\
\hline & $(1.419)$ & $(0.221)$ & $(0.331)$ & $(0.497)$ \\
\hline \multirow[t]{2}{*}{ TENURE $^{2}$} & $-0.101 * *$ & 0.004 & -0.001 & -0.006 \\
\hline & $(0.040)$ & $(0.005)$ & $(0.008)$ & $(0.014)$ \\
\hline \multirow[t]{2}{*}{ POWER } & $22.620^{*}$ & 0.905 & -3.861 & -5.864 \\
\hline & (12.719) & $(2.763)$ & $(3.464)$ & $(5.610)$ \\
\hline \multirow[t]{2}{*}{ POWER*TENURE } & $-3.637 * * *$ & -0.086 & $-0.494 * * *$ & $-0.829 * * *$ \\
\hline & $(0.967)$ & $(0.130)$ & $(0.183)$ & $(0.249)$ \\
\hline \multirow{2}{*}{ GNI } & $0.027 * * *$ & 0.003 & $0.017 * * *$ & $0.035 * * *$ \\
\hline & $(0.006)$ & $(0.002)$ & $(0.003)$ & $(0.006)$ \\
\hline \multirow[t]{2}{*}{ OPENNESS } & $1.587 * * *$ & 0.037 & 0.056 & 0.091 \\
\hline & $(0.463)$ & $(0.028)$ & $(0.048)$ & $(0.148)$ \\
\hline \multirow[t]{2}{*}{ GOV-EXP } & $-5.118 * *$ & -0.056 & 0.045 & -0.371 \\
\hline & $(2.019)$ & $(0.132)$ & $(0.212)$ & $(0.536)$ \\
\hline \multirow[t]{2}{*}{ RER } & 0.005 & 0.002 & -0.000 & $-0.004^{*}$ \\
\hline & $(0.011)$ & $(0.001)$ & $(0.002)$ & $(0.002)$ \\
\hline \multirow[t]{2}{*}{ ETHNIC_DIV } & -6.583 & $-7.616^{* *}$ & 0.983 & 7.638 \\
\hline & $(19.081)$ & $(3.822)$ & (3.888) & $(8.540)$ \\
\hline CIVIL & $22.170 * * *$ & 0.189 & 0.730 & 1.064 \\
\hline Observations & 531 & 531 & 531 & 531 \\
\hline $\mathrm{R}^{2}$ & 0.455 & 0.037 & 0.188 & 0.392 \\
\hline
\end{tabular}

Note: Robust standard errors in parenthesis in Columns (1) and (2); Bootstrap standard errors in parenthesis in Columns (3) and (4); Quantile regression standard errors are based on bootstrap with 400 replications;

Significance levels: $* * * \mathrm{p}<0.01, * * \mathrm{p}<0.05, * \mathrm{p}<0.1$ 


\section{Appendix}

Table A-1: Correlation Matrix: FDI per Capita and Other Determinants in the Regression

\begin{tabular}{|c|c|c|c|c|c|c|c|c|c|c|c|c|}
\hline & FDI & ABROAD & AFRICA & NO EDU & TENURE & POWER & GNI & $\begin{array}{l}\text { OPEN- } \\
\text { NESS }\end{array}$ & $\begin{array}{l}\text { GOV- } \\
\text { EXP }\end{array}$ & RER & ETHNIC & CIVIL \\
\hline FDI & 1 & & & & & & & & & & & \\
\hline ABROAD & 0.2226 & 1 & & & & & & & & & & \\
\hline AFRICA & -0.139 & -0.5063 & 1 & & & & & & & & & \\
\hline NO EDU & -0.1022 & -0.5659 & -0.4245 & 1 & & & & & & & & \\
\hline TENURE & 0.1827 & -0.1106 & 0.0548 & 0.0637 & 1 & & & & & & & \\
\hline POWER & 0.0065 & 0.1307 & 0.1606 & -0.2908 & 0.1053 & 1 & & & & & & \\
\hline GNI & 0.546 & 0.1116 & -0.1754 & 0.0497 & 0.3134 & 0.112 & 1 & & & & & \\
\hline OPENNESS & 0.4529 & 0.2485 & -0.2901 & 0.0177 & 0.134 & 0.1253 & 0.5092 & 1 & & & & \\
\hline GOV-EXP & 0.0479 & 0.1186 & 0.0159 & -0.1399 & -0.1218 & 0.1112 & 0.2032 & 0.4677 & 1 & & & \\
\hline RER & 0.0084 & -0.0869 & 0.0315 & 0.0614 & 0.1677 & -0.0962 & -0.0266 & -0.0699 & -0.2646 & 1 & & \\
\hline ETHNIC & -0.2859 & -0.1133 & -0.1717 & 0.2886 & 0.0016 & 0.0668 & -0.3855 & -0.3173 & -0.239 & 0.1528 & 1 & \\
\hline CIVIL & -0.0355 & -0.0838 & -0.058 & 0.1437 & -0.1232 & -0.2106 & -0.2942 & -0.1996 & -0.1355 & -0.0003 & 0.1056 & 1 \\
\hline
\end{tabular}

